\title{
Effect of elevated UV dose and alkalinity on metaldehyde removal and THM formation with $\mathrm{UV} / \mathrm{TiO}_{2}$ and $\mathrm{UV} / \mathrm{H}_{2} \mathrm{O}_{2}$
}

Bruce Jefferson*, Peter Jarvis, Govind Kannoly Bhagianathan, Heather Smith, Olivier Autin, Emma Harriet Goslan, Jitka MacAdam and Irene Carra.

Cranfield Water Science Institute, Cranfield University, Bedfordshire, MK43 OAL, UK ${ }^{*}$ Author for correspondence: $\underline{\text { b.jefferson@cranfield.ac.uk }}$

\begin{abstract}
Drinking water production needs to increasingly consider removal of background organic matter and trace micropollutants without increasing disinfection-by-product (DBP) formation potential. The presented data demonstrates the efficacy of both $\mathrm{UV} / \mathrm{H}_{2} \mathrm{O}_{2}$ and $\mathrm{UV} / \mathrm{TiO}{ }_{2}$ in removing the pesticide metaldehyde to below drinking water compliance levels in both real and synthetic waters. This pesticide has proven to be unaffected by conventional water treatment processes such as granular active carbon and is responsible for many of the water company compliance failures in the UK. The potential of $\mathrm{UV} / \mathrm{H}_{2} \mathrm{O}_{2}$ is further demonstrated to offer an alternative approach for the removal of recalcitrant organic matter to ensure DBP compliance as long as extended UV doses of over $10000 \mathrm{~mJ} \mathrm{~cm}^{-2}$ are applied at the optimum peroxide dose of $8 \mathrm{mM}$. Alkalinity and UV dose have an impact on DBP formation: at low UV fluences, increased alkalinity reduced the $\mathrm{DBP}$ formation. The $\mathrm{UV} / \mathrm{TiO}_{2}$ process was observed to be inhibited in the presence of alkalinity. Aggregation studies and comparison of the catalyst fractal dimension showed that the process inhibition is mainly due to aggregation. This restricts the surface area available for reactions, rather than changes in the catalyst properties or carbonate radical scavenging, which is often the reasoning attributed to photocatalysis inhibition. Hence, the presented results indicate that decreasing the catalyst aggregation is the key to apply photocatalysis as drinking water treatment.
\end{abstract}


Keywords: aggregation, advanced oxidation processes, disinfection-by product, drinking water, metaldehyde, photocatalysis

\section{Introduction}

The need to remove micropollutants from drinking water sources is of growing concern due to an increase in their occurrence [1,2] and our understanding of the adverse effects they may have on human health $[3,4,5]$. Accordingly, adaptation of existing water treatment facilities is required to extend their capability beyond removal of bulk dissolved organic carbon (DOC), turbidity and microorganisms to also include removal of trace concentration of specific micropollutants. Some steps have been given towards this direction, with ozone processes and activated carbon being the most significant additions to water plants

One of the most recurrent groups of pollutants are pesticides as modern formulations tend to produce compounds which are uncharged, of low molecular weight and persistent to conventional treatment. Consequently, water plants have to be adapted to meet the European Union drinking water standard of $0.1 \mu \mathrm{g} \mathrm{L}^{-1}$ for all individual pesticides and a maximum allowable limit of $0.5 \mu \mathrm{g} \mathrm{L}^{-1}$ for the sum of all pesticides [6]. The problem of effectively treating pesticides can be illustrated through the case of the pesticide metaldehyde, which has been found to by-pass drinking water treatment [7]. Metaldehyde was first identified in drinking water in the UK in 2007 and was reported in 2014 to be responsible for $61 \%$ of the water company failures due to pesticides in the UK [8]. Similar concerns exist across Europe for other recalcitrant pesticides such as triazine pesticides $[9,10]$ and the pyridine pesticide clopyralid [11]. The result of these concerns means that alternative approaches are required at drinking water treatment plants (WTPs).

The most common adaptation at a WTP to deal with persistent compounds involves the inclusion of either membranes [12] or chemical processes such as advanced oxidation 
processes (AOPs) $[13,14]$. One group of AOPs utilises UV irradiation to start a selection of different reactions to produce the highly reactive hydroxyl radical ( $\left.\mathrm{HO}^{\circ}\right)$ in water. The processes used in combination with UV include heterogeneous photocatalysis $\left(\mathrm{UV} / \mathrm{TiO}_{2}\right)$ and hydrogen peroxide photolysis $\left(\mathrm{UV} / \mathrm{H}_{2} \mathrm{O}_{2}\right)$. The key difference between both is the phase in which the reaction occurs. In the $\mathrm{UV} / \mathrm{H}_{2} \mathrm{O}_{2}$ process, the free radicals are formed in the liquid phase and can directly react in solution. Whereas $\mathrm{TiO}_{2}$ is a solid catalyst such that the free radicals form at the catalyst surface limiting reactions to the proximity of the catalyst. A large number of complex reactions are involved in AOPs and the rate of oxidation will generally vary with the $\mathrm{HO}^{\circ}$ generation rate, oxygen and pollutant concentrations, among other parameters. Whilst the efficacy of AOPs has been shown previously in many studies [14, 15], the impact of the background matrix remains an active area of investigation focused mainly on understanding the impact of the competing organic and inorganic species typically present in source waters $[16,17]$.

A logical extension to this line of investigation leads to the consideration of AOPs for bulk DOC removal. Their potential has been demonstrated previously with DOC removals as high as $87 \%$ reported for the photocatalysis of a raw water containing $2.3 \mathrm{mg} \mathrm{L}^{-1} \mathrm{DOC}[18]$ and around $80 \%$ for a reservoir surface water with an initial DOC of around $10 \mathrm{mg} \mathrm{L}^{-1}[19]$. The nature and concentration of organic matter in raw waters, which often depends on geological conditions, has an impact in the performance of AOPs. Hydrophobic and high molar mass compounds have been reported to be better oxidised by heterogeneous photocatalysis or hydrogen peroxide photolysis; while low molar mass compounds would be better degraded by the photoFenton process [20]. Another issue of particular concern for drinking water treatment is the formation of disinfection by-products (DBPs). One of regulated DBP groups in the UK are trihalometanes (THMs). In the UK, a maximum concentration value of $100 \mu \mathrm{g} \mathrm{L}^{-1}$ at the consumer's tap has been set for the sum of trichloromethane, bromodichloromethane, dibromochloromethane, tribromomethane [21] and they are also subject to WHO guidelines due to their potential health risk [22]. Therefore, studying the impact of AOP treatment on DBP 
formation is of special interest. Typical UV doses for drinking water treatment are in the order of $1000-5000 \mathrm{~mJ} \mathrm{~cm}^{-2}$ [23] but it has been suggested that higher UV doses could be required for both micropollutants removal and DBP formation reduction [24]. As an example, the need to apply sufficient UV dose has also been demonstrated for two hydrophilic surface waters, where sub-optimum photocatalysis increased the THM formation potential (THMFP) in the water [25]. The required fluences would restrict the economic suitability of the solution but the development in low energy UV delivery with UV-LEDs offers a promise for the near future when their efficiency is improved.

The current paper builds on such findings by examining the impact of high UVC dose in terms of micropollutant, bulk DOC removal and THMFP in drinking water for UV/TiO and $\mathrm{UV} / \mathrm{H}_{2} \mathrm{O}_{2}$ and the effect of different alkalinity concentrations on the process performance. To this end, synthetic and natural waters were used at different alkalinity concentrations. Metaldehyde was selected as model micropollutant whereas three organic compounds were selected as bulk organic matter surrogates (serine, leucine and resorcinol) due their hydrophilic/hydrophobic nature.

\section{Materials and Methods}

\subsection{Chemicals}

Metaldehyde, serine, leucine, hydrogen peroxide $(35 \% \mathrm{w} / \mathrm{w}), \mathrm{CaCl}_{2}$ and $\mathrm{NaHCO}_{3}$ were obtained from Fisher Scientific.Resorcinol, ammonium acetate, formic acid and acetonitrile were acquired from Sigma-Aldrich at analytical purity or above. Titanium dioxide (Aeroxide ${ }^{\circledR}$ $\mathrm{TiO}_{2}$ P25 Degussa) was purchased from Lawrence Industries (Tamworth, UK). All synthetic solutions were prepared in ultrapure water (Purelab Option - S7/15, $18.2 \mathrm{M} \Omega \mathrm{cm}$ and TOC < $3 \mathrm{ppb})$.

\subsection{Experimental set-up}


$\mathrm{UV} / \mathrm{TiO}_{2}$ and $\mathrm{UV} / \mathrm{H}_{2} \mathrm{O}_{2}$ experiments were all conducted in a Wedeco AG bench scale quasicollimated beam apparatus (Herford, Germany) equipped with four 30 W UVC low pressure lamps emitting monochromatic light at $254 \mathrm{~nm}$. A volume of $250 \mathrm{~mL}$ of test solution was placed in a Petri dish at $22 \mathrm{~cm}$ from the light source and stirred. UV irradiance was determined to be 23.3 $\mathrm{W} \mathrm{m}^{-2}$ using the uridine actinometry method as described by von Sonntag and Schuchmann [26].

The experiments were conducted using synthetic water and a natural sample taken from a water treatment plant (WTP) in the Severn Trent Water region in the UK. The synthetic water contained a mixture of surrogate compounds: serine, leucine and resorcinol. These compounds have been previously used as surrogate compounds since they are good representatives of the organic matter found after coagulation treatment [27]. The properties of the compounds are shown in Table 1. Leucine represents the hydrophilic fraction, serine the transphilic fraction, and resorcinol the hydrophobic fraction as identified by their octanol-water partition coefficient (Table 1). This is important when the THMFP is studied since the hydrophilic and hydrophobic characteristics of organic matter have an impact on THM formation [28]. Therefore it is important to have representatives of both fractions in the synthetic water. Additionally, these compounds were selected for their low adsorption properties and low reactivity with hydroxyl radicals in comparison with metaldehyde (Table 1), making them a good choice as bulk organic matter [16]. Surrogates were added in quantities to deliver the same DOC concentration each, adding a total DOC of $5 \mathrm{mg} \mathrm{L}^{-1}$ (4.6 mg L-1 serine, $3 \mathrm{mg} \mathrm{L}^{-1}$ leucine, $2.4 \mathrm{mg} \mathrm{L}^{-1}$ resorcinol). Metaldehyde was used as the target micropollutant at a concentration of $10 \mu \mathrm{g} \mathrm{L}^{-1}$.

The effect of alkalinity and hardness on $\mathrm{TiO}_{2}$ aggregation was also studied. The former was evaluated through addition of $\mathrm{NaHCO}_{3}$ and covered the range of alkalinity values typically seen in UK drinking waters $\left(5-120 \mathrm{mg} / \mathrm{L}\right.$ expressed as $\left.\mathrm{CaCO}_{3}\right)$; the latter was studied through 
the addition of $\mathrm{CaCl}_{2}$ as $\mathrm{Ca}^{2+}$ source, also in the range of common values found in the UK (5$120 \mathrm{mg} \mathrm{L}^{-1}$ expressed as $\left.\mathrm{CaCO}_{3}\right) \cdot \mathrm{pH}$ of the water was not adjusted.

The natural water was collected post-GAC treatment and had a DOC of $3.5 \mathrm{mg} \mathrm{L}^{-1}(26.5 \%$, $25.3 \%$ and $48.3 \%$ of hydrophobic, transphilic and hydrophilic fractions respectively) and an alkalinity of $120 \mathrm{mg} \mathrm{L}^{-1}$ expressed as $\mathrm{CaCO}_{3}$. All water samples were stored in the dark at $4^{\circ} \mathrm{C}$ until used for experiments.

Both $\mathrm{UV} / \mathrm{TiO} \mathrm{O}_{2}$ and $\mathrm{UV} / \mathrm{H}_{2} \mathrm{O}_{2}$ experiments were conducted using the optimum dose of chemical for metaldehyde removal. These were $100 \mathrm{mg} \mathrm{L}^{-1}\left(\mathrm{TiO}_{2}\right)$ and $8 \mathrm{mM}$ or $272 \mathrm{mg} \mathrm{L}^{-1}\left(\mathrm{H}_{2} \mathrm{O}_{2}\right)$ [29]. The system was continuously mixed with a magnetic stirrer. All experiments were carried out at natural $\mathrm{pH}(7.8-8.2)$ with the exception of synthetic water without $\mathrm{NaHCO}_{3}$ where the $\mathrm{pH}$ was 6.7-7.0. The experiments were run at room temperature $\left(20-22^{\circ} \mathrm{C}\right)$. Evaporation was negligible during the experiments. Adsorption of metaldehyde, resorcinol, leucine and serine on $\mathrm{TiO}_{2}$ was found to be negligible after $2 \mathrm{~h}$. Photolysis of the four compounds was carried out as blank and found insignificant except for serine, which was degraded $20 \%$ after a dose of $3000 \mathrm{~mJ} \mathrm{~cm}^{-2}$. The experiments were carried out in duplicate. The experimental errors for metaldehyde, leucine, serine, resorcinol, DOC and THMs were $3.2 \%, 4.3 \%, 2.9 \%, 6.9 \%, 4.1 \%$ and $8.7 \%$, respectively.

\subsection{Analytical methods}

For $\mathrm{UV} / \mathrm{TiO}_{2}$, samples were filtered through $0.45 \mu \mathrm{m}$ syringe filters (Millex-HA) before analysis to separate the $\mathrm{TiO}_{2}$ particles from the treated water prior to analysis. For $\mathrm{UV} / \mathrm{H}_{2} \mathrm{O}_{2}$ experiments samples were directly analysed after each experiment. The absorbance at 254 $\mathrm{nm}$ was measured with a UV-Vis spectrophotometer (Jenway, UK) and DOC measured as non-purgeable organic carbon (NPOC) using a Shimadzu 5000A TOC analyser. The alkalinity was measured by $\mathrm{HCl}$ titrimetric method 2320B [30]. 
The size and fractal dimension of the $\mathrm{TiO}_{2}$ aggregates were measured using laser diffraction (Malvern Mastersizer 2000, Malvern Instruments, UK) according to the methods outlined by Jarvis et al. [31]. The suspension was monitored by drawing water through the optical unit of the Mastersizer and back into the jar by a peristaltic pump. The inflow and outflow tubes were positioned opposite one another at a depth just above the paddle in the holding ports. Size measurements were taken every minute for the duration of the jar test and logged onto a PC.

Quantification of the concentration of each specific compound was performed using a Waters 2695 LC system coupled with a Waters Quattro Premier Xe MS-MS. The aqueous mobile phase $A$ consisted of $5 \mathrm{mM}$ ammonium acetate $/ 0.1 \%$ formic acid and the organic mobile phase B was acetonitrile/ $0.1 \%$ formic acid. The flow rate was set to $0.2 \mathrm{~mL} \cdot \mathrm{min}^{-1}$ and the conditions were $50 \% \mathrm{~A}$ and $50 \%$ B held for 2 minutes. The Quattro Premier Xe tandem quadruple MS was operated under positive electrospray ionization mode for metaldehyde, leucine and serine and negative electrospray ionization mode for resorcinol. The instrument was operated in multiple reaction monitoring set to monitor ions m/z 194 for metaldehyde, $\mathrm{m} / \mathrm{z} 131.7$ for leucine, $\mathrm{m} / \mathrm{z} 105.7$ for serine and m/z 108.5 for resorcinol. Source conditions were as follows: capillary $3.5 \mathrm{kV}$, source temperature $120{ }^{\circ} \mathrm{C}$, desolvation temperature $350{ }^{\circ} \mathrm{C}$, and nitrogen drying gas $1000 \mathrm{~L} \mathrm{~h}^{-1}$. Calibration curves were generated prior to each new sequence for each compound and the concentrations were determined using Micromass QuantLynx. Limits of detection for metaldehyde, leucine, serine and resorcinol were $0.5,0.8,1.2$ and $1.6 \mu \mathrm{g} / \mathrm{L}$, respectively. The column was a Gemini $3 \mu \mathrm{m}$ C18 110A $(100 \times 2.0 \mathrm{~mm})$ (Phenomenex, Cheshire, UK).

THMFP was measured using an adapted version of USEPA method 551.1. UV $-\mathrm{H}_{2} \mathrm{O}_{2}$ samples were quenched with magnesium oxide (99\%) to remove all residual $\mathrm{H}_{2} \mathrm{O}_{2}$. All samples were filtered and diluted 5 times with UP water before being chlorinated at 5 mass ratio $\left(\mathrm{Cl}_{2}\right.$ : $\left.\mathrm{DOC}\right)$ and then buffered to $\mathrm{pH} 7$ with a phosphate buffer solution. The chlorinated samples were stored in $100 \mathrm{~mL}$ PTFE bottles for 7 days after which time the residual chlorine was quenched with sodium sulphite $\left(0.3 \mathrm{~mL}\right.$ of $20 \mathrm{~g} \cdot \mathrm{L}^{-1}$ solution in a $40 \mathrm{~mL}$ vial). The $\mathrm{pH}$ of all samples was 
then standardized to $4.8-5.5$ by addition of $1 \mathrm{~g}$ of a buffer containing $1 \%$ sodium phosphate dibasic and $99 \%$ potassium phosphate monobasic. The THMs were then extracted by addition of $2 \mathrm{~mL}$ of methyl tert-butyl ether and $14 \mathrm{~g}$ sodium sulphate. The top layer was transferred to a GC vial and analysed for THMs using a gas chromatograph with electron capture detector (Agilent 6890 GC-ECD). The THMs detected were trichloromethane, dichlorobromomethane, dibromochloromethane and tribromomethane. A capillary column (ZB-1ms column (Phenomenex, UK) $30 \mathrm{~m} \times 0.25 \mathrm{~mm} \times 0.25 \mu \mathrm{m}$ ) was used with helium carrier gas at a constant linear velocity of $25 \mathrm{~cm} / \mathrm{second}$. The split ratio was set at $10: 1$. A volume of $1 \mu \mathrm{L}$ was injected. The initial oven temperature was $35^{\circ} \mathrm{C}$ held for 22 minutes followed by a $10^{\circ} \mathrm{C}$ per minute temperature ramp to $145^{\circ} \mathrm{C}$ and held for 2 minutes. The temperature was increased to 225 ${ }^{\circ} \mathrm{C}$ at a rate of $20^{\circ} \mathrm{C} /$ minute and held for 15 minutes followed by an increase to $260{ }^{\circ} \mathrm{C}$ at a rate of $10^{\circ} \mathrm{C} /$ minute and held for 30 minutes. The temperature of the injector was set at $200^{\circ} \mathrm{C}$ and the detector at $290^{\circ} \mathrm{C}$.

\section{Results and Discussion}

\subsection{Comparison in synthetic water}

Both UV/TiO 2 and UV/ $\mathrm{H}_{2} \mathrm{O}_{2}$ systems were carried out using UVC light, dosing up to $40000 \mathrm{~mJ}$ $\mathrm{cm}^{-2}$ (Figure 1). The sequence of removal of the bulk organic matter with respect to UV dose was consistent with the molar extinction coefficients of the individual compounds (Table 1). UVC doses of 3000,5000 and $10000 \mathrm{~mJ} \mathrm{~cm}^{-2}$ were required to reduce the concentration of resorcinol, leucine and serine to below detection with photocatalysis. In the case of $U V / \mathrm{H}_{2} \mathrm{O}_{2}$ doses of 5000 and $10000 \mathrm{~mJ} \mathrm{~cm}^{-2}$ were required demonstrating an equivalent efficacy for both AOPs.

These results are also consistent with the nature of the organic matter. Resorcinol is a hydrophobic compound (Table 1) with an aromatic ring, which makes it an easy target for hydroxyl radicals through electrophilic addition. In the case of leucine and serine, they are 
hydrophilic substances with lower reactivity towards hydroxyl radicals than resorcinol (Table 1).

In the case of metaldehyde, the target micropollutant was removed at irradiation doses with the same order of magnitude in both processes, 5000 and $3000 \mathrm{~mJ} \mathrm{~cm}{ }^{-2}$ with $\mathrm{UV} / \mathrm{TiO}_{2}$ and $\mathrm{UV} / \mathrm{H}_{2} \mathrm{O}_{2}$, respectively. Importantly, metaldehyde was effectively removed in the presence of high molar ratios of background organic matter demonstrating the efficacy of both AOPs as a pesticide treatment, provided conditions are optimised and a sufficient UV dose is applied to meet the scavenging demand of the competing species [29]. In the case of $U V / \mathrm{H}_{2} \mathrm{O}_{2}$ it should be pointed out that, although the concentration of hydrogen peroxide required to achieve fast metaldehyde removal is high $(8 \mathrm{mM})$, the residual concentration can be quenched with innocuous sodium sulphite, which is oxidised to sulphate.

With respect to DOC, the difference between the AOPs was greater. $U V / \mathrm{H}_{2} \mathrm{O}_{2}$ could only achieve $60 \%$ mineralisation after dosing $40000 \mathrm{~mJ} \mathrm{~cm}^{-2}$; while for $\mathrm{UV} / \mathrm{TiO}_{2} 85 \%$ mineralization could be obtained for the same irradiation fluence. It should be pointed out that the DOC removal was faster at the beginning of both AOPs (Figure 1), especially with photocatalysis, where $65 \%$ mineralisation was already achieved after $5000 \mathrm{~mJ} \mathrm{~cm}^{-2}$. As the oxidation process progressed, mineralisation was slowed. This effect has been reported in other works and attributed to the formation of aliphatic organic acids which present low reactivity towards the hydroxyl radicals and this was common for both hydroxyl radical-based processes [32]. The difference in the performance between $\mathrm{UV} / \mathrm{H}_{2} \mathrm{O}_{2}$ and $\mathrm{UV} / \mathrm{TiO} \mathrm{O}_{2}$ is related to the intrinsic mechanism for the formation of radicals. The generation of radicals via photocatalysis occurs in the heterogeneous phase, i.e. the catalyst surface. When the catalyst, a semiconductor, is illuminated, the absorption of photons provokes the migration of electrons from the valence to the conduction band, giving place to an electron-hole pair (Equation 1). Then, the holes can oxidise water (Equation 2), hydroxyl groups (Equation 3) or other organic matter present (Equation 4) [33]. In comparison, hydrogen peroxide leads to the generation of hydroxyl 
radicals through photolysis of the $\mathrm{H}_{2} \mathrm{O}_{2}$ molecules, with a molecular extinction coefficient of approximately $20 \mathrm{M}^{-1} \mathrm{~cm}^{-1}$ at $254 \mathrm{~nm}$. This value is rather low in comparison to other compounds such as ozone $\left(3300 \mathrm{M}^{-1} \mathrm{~cm}^{-1}\right)[34]$.

$$
\begin{aligned}
& \mathrm{TiO}_{2}+\mathrm{h}_{v} \rightarrow \mathrm{e}^{-}+\mathrm{h}^{+} \\
& \mathrm{h}^{+}+\mathrm{H}_{2} \mathrm{O} \rightarrow \mathrm{HO}^{\circ} \\
& \mathrm{h}^{+}+\mathrm{OH}^{-} \rightarrow \mathrm{HO}^{\circ} \\
& \mathrm{h}^{+}+\text {organic matter } \rightarrow \mathrm{HO}^{\circ}
\end{aligned}
$$

\subsection{Influence of UVC dose in natural water}

Equivalent trials using a natural water source were carried out. The key difference between the natural water and the synthetic water was the presence and absence of alkalinity respectively, with the natural water having an alkalinity of $120 \mathrm{mg} \mathrm{L}^{-1}$ expressed as $\mathrm{CaCO}_{3}$. Under these conditions the UV dose needed by $\mathrm{UV} / \mathrm{TiO}_{2}$ to remove metaldehyde was 40000 $\mathrm{mJ} \mathrm{cm}^{-2}$ (Figure 2) rather than the $5000 \mathrm{~mJ} \mathrm{~cm}^{-2}$ needed in the synthetic water without alkalinity (Figure 1a). In the case of $\mathrm{UV} / \mathrm{H}_{2} \mathrm{O}_{2}$ the UV dose was $5000 \mathrm{~mJ} \mathrm{~cm}{ }^{-2}$, similar to the value needed in the synthetic water. The metaldehyde pseudo-first order constant was obtained for the degradation with both AOPs in the natural water, being 12 times higher with $U V / \mathrm{H}_{2} \mathrm{O}_{2}$ than UV/TiO $2\left(0.597 \mathrm{~h}^{-1}\right.$ versus $\left.7.058 \mathrm{~h}^{-1}\right)$. Similarly, after a UV fluence of $3000 \mathrm{~mJ} \mathrm{~cm}^{-2} \mathrm{DOC}$ concentration was stabilised at $90 \%$ with $\mathrm{UV} / \mathrm{TiO}_{2}$, even after dosing $40000 \mathrm{~mJ} \mathrm{~cm}^{-2}$. However, over $60 \%$ removal was achieved with $\mathrm{UV} / \mathrm{H}_{2} \mathrm{O}_{2}$ for the same UVC dose, which corresponds to the removal obtained in the synthetic water.

The presence of alkalinity significantly affects photocatalysis efficiency. The point of zero charge for $\mathrm{TiO}_{2} \mathrm{P} 25$, the most common of the $\mathrm{TiO}_{2}$ types and used in this work, is close to neutral $\mathrm{pH}$. The closer the water $\mathrm{pH}$ is to the point of zero charge, the lower the electrostatic potential is. As a result, the catalyst particles begin to agglomerate forming aggregates up to $4 \mathrm{~mm}$ in diameter [33]. The effect decreases the available holes in the catalyst surface and therefore reduces the process effectiveness. This effect is further studied in Section 3.4. 


\subsection{Impact of UVC dose on THMFP}

Another important aspect of the treatment is the influence of the UV dose on THMFP. AOP transformation by-products are an issue of concern for water scientists and in the case of drinking water, DBPs constitute a transformation by-product group of concern.

A great difference in THMFP was observed between both AOPs in natural and synthetic water (Figure 3). The impact of partial organic matter degradation at lower UV fluences was shown during $\mathrm{UV} / \mathrm{TiO}_{2}$ treatment in synthetic water where it was observed that THMFP increased after an initial drop to $200 \mu \mathrm{g} \mathrm{mg}^{-1}$ at $1000 \mathrm{~mJ} \mathrm{~cm}^{-2}$ to $400 \mu \mathrm{g} \mathrm{mg}^{-1}$ at $4000 \mathrm{~mJ} \mathrm{~cm}^{-2}$ and remained above $280 \mu \mathrm{g} \mathrm{mg}^{-1}$ thereafter. Such observations are in agreement with previous reports of increasing THMFP from partially degraded organic matter typically found in hydrophilic waters [19] and from the hydrophilic model compound leucine [35]. A coupling of maximum DOC removal and an increase in THMFP has also been reported when exposing high $\mathrm{TiO}_{2}$ concentrations to extended UV fluences [36].

However, the THMFP response with the $\mathrm{UV} / \mathrm{H}_{2} \mathrm{O}_{2}$ system was very different to the $\mathrm{UV} / \mathrm{TiO}{ }_{2}$ system (Figure 3). Commensurate THMFP data was consistently lower than in the case of $\mathrm{UV} / \mathrm{TiO}_{2}$, reducing from a raw water level of $332 \mu \mathrm{g} \mathrm{mg}{ }^{-1}$ down to between 19 and $52 \mu \mathrm{g} \mathrm{mg}^{-1}$ across all applied fluences in the case of the synthetic water and from $445 \mu \mathrm{g} \mathrm{mg}^{-1}$ to $70 \mu \mathrm{g}$ $\mathrm{mg}^{-1}$ in the natural water. The divergence in THM formation that occurs when identical mixtures of organic compounds are treated by the two AOPs infers the formation of different degradation by-products. Identification of the degradates was not undertaken here, however previous studies have demonstrated that DBP formation potential relates to chlorine substitution efficiency as opposed to either chlorine demand or the physiochemical properties of the molecules [28]. In the case of high THMFP, as observed in this work when applying $\mathrm{UV} / \mathrm{TiO}_{2}$ to a mixture, high chlorine demand and high chlorine substitution efficiency is congruent with the presence of organic matter composed of activated aromatic compounds, 
b-dicarbonyls and amino acids type molecules. In terms of THM speciation, in synthetic water total THMs were represented totally by trichloromethane; and in the case of natural water, this species represented more than 92\%, the rest being bromodichloromethane and dibromochloromethane.

Translation of THMFP data to anticipated THM levels in practice remains an area on ongoing discussion with published correlations, suggesting a conversion factor of 0.199 from the THMFP to the THM after 24 hours [37]. Current regulations in the UK has moved to a risk assessment approach for controlling DBPs such that sites exceeding $50 \mu \mathrm{g} \mathrm{L}^{-1} \mathrm{THMs}$ have to be reported to the regulator. This level of THMs equates to a THMFP of $250 \mu \mathrm{g} \mathrm{mg}^{-1}$ based on the correlation above. Correspondingly, both AOPs were therefore able to directly treat raw water to a level that would meet DBP legislation without the need for a risk assessment, with a required UV dose of $35000 \mathrm{~mJ} \mathrm{~cm}^{-2}$ for $\mathrm{UV} / \mathrm{TiO}_{2}$ and around $10000 \mathrm{~mJ} \mathrm{~cm}{ }^{-2}$ for $\mathrm{UV} / \mathrm{H}_{2} \mathrm{O}_{2}$.

\subsection{Performance of $\mathrm{UV} / \mathrm{TiO}_{2}$ at different UVC doses and alkalinity concentration}

To elucidate the impact of alkalinity on the $\mathrm{UV} / \mathrm{TiO}_{2}$ process a further set of experiments were conducted on the synthetic water supplemented with varying amounts of alkalinity (Figures 47). Addition of even trace amounts of alkalinity reduced the efficacy of the photocatalytic process for DOC removal with the observed loss of removal increasing in accordance with the supplemented alkalinity concentration.

To better investigate the influence of alkalinity on the kinetics, k', the pseudo-first order constants for metaldehyde and DOC concentrations were obtained (Figure 4). A similar trend was observed for both, where the increase in alkalinity gave rise to an exponential decrease in the kinetic constant. For metaldehyde, $\mathrm{k}^{\prime}$ decreased from $2.7 \mathrm{~h}^{-1}$ in the absence of alkalinity to a stabilised value of $1.8 \mathrm{~h}^{-1}, 1.9$ times slower, for alkalinity above $60 \mathrm{mg} / \mathrm{L}$ as $\mathrm{CaCO}_{3}$. In contrast, the effect on DOC was more marked, as k' decreased by a factor of 19 times in the 
presence of alkalinity up to $60 \mathrm{mg} / \mathrm{L}$ (from 1.4 to $0.09 \mathrm{~h}^{-1}$ ). This has to do with the fact that DOC mineralisation involves several oxidation steps beyond the initial oxidation of the parent molecule.

The impact of alkalinity on THMFP was also assessed (Figure 5). For all alkalinity values, an increase in the UV dose decreased the THMFP following an exponential decay. At the same time, it was also observed that for a given UV dose below $5000 \mathrm{~mJ} \mathrm{~cm}^{-2}$ as alkalinity increased the THMFP decreased (e.g. from approximately $590 \mu \mathrm{g} \mathrm{L}^{-1}$ with no alkalinity to $300 \mathrm{\mu g} \mathrm{L}^{-1}$ with $60 \mathrm{mg} \mathrm{L}^{-1}$ of alkalinity. Above this UV dose, between 10000 and $30000 \mathrm{~mJ} \mathrm{~cm}^{-2}$, the THMFP was $256 \pm 71 \mu \mathrm{g} \mathrm{L^{-1 }}$ for all alkalinity concentrations. The reduction in THMFP in the higher alkalinity cases at low fluences reflects the inhibition of degradation such that increasing amounts of the total DOC are still derived from the parent molecules. At low UV fluences, increased alkalinity reduced the THMFP whereas at higher fluences increased alkalinity did not increase THMFP. The observations are congruent with the synthetic organic compound experiments, where partial degradation of the parent molecules initially lowered THMFP but then increased as further degradation occurs.

In terms of pollutant degradation, and as explained in Section 3.2, the presence of alkalinity reduces photocatalysis efficiency due to particle aggregation. Alkalinity derived inhibition has also been attributed to hydroxyl radical scavenging by the carbonate radical [38, 39]. However, this has been found to be applicable in cases where only trace organics are present. In situations where bulk DOC is present, such as the current study, alkalinity only contributes between 1.8 and $12.7 \%$ of the total scavenging rate [16]. Support for this is provided in the current study from the $\mathrm{UV} / \mathrm{H}_{2} \mathrm{O}_{2}$ process where no significant inhibition took place confirming that scavenging was not the dominant mechanism as it would equally apply to both AOPs.

Therefore, a subsequent study was made on particle size. The analysis was carried out to study alkalinity-based aggregation of $\mathrm{TiO}_{2}$ (Figure 6). In the absence of alkalinity, the median 
aggregate size was $3.5 \mu \mathrm{m}$, which is a standard value for Degussa P25 [33]. Addition of $5 \mathrm{mg}$ $\mathrm{L}^{-1}$ of alkalinity increased the median particle size to $40.7 \mu \mathrm{m}$ which increased in median size to $120.2 \mu \mathrm{m}, 440.9 \mu \mathrm{m}$ and $456.6 \mu \mathrm{m}$ with the addition of $60 \mathrm{mg} \mathrm{L}^{-1}, 80 \mathrm{mg} \mathrm{L}^{-1}$ and $120 \mathrm{mg} \mathrm{L}^{-}$ 1 respectively. This is in agreement with the kinetic constant profiles obtained at different alkalinities (Figure 4), where it was shown that alkalinity above $60 \mathrm{mg} \mathrm{L}^{-1}$ resulted in a stabilised kinetic constant for DOC and metaldehyde degradation. These results show that the decrease in the process rate was due to the aggregation effect the catalyst goes through in the presence of alkalinity. To separate the possible effect of hardness on aggregation from alkalinity, additional experiments were made adding calcium (from 0 to $120 \mathrm{mg} \mathrm{L}^{-1}$ expressed as $\mathrm{CaCO}_{3}$ ). Results showed that there was no aggregation effect with hardness up to $40 \mathrm{mg}$ $\mathrm{L}^{-1}$. Only slight aggregation effects could be observed with a hardness value of $120 \mathrm{mg} \mathrm{L}^{-1}$, where particle size was $10.4 \mu \mathrm{m}$ (data added as supplementary information) (Figure S1).

The inference from the aggregation of $\mathrm{TiO}_{2}$ is that it reduces the available surface area for reaction, although this needs to be considered in relation to be the dendritic nature of aggregates and the local volumetric rate of photon absorption [40]. The latter defines the volume space around the irradiation source where catalyst activation occurs and consequently only the proportion of the catalyst that enters this zone will result in being available for degradation. In the case of $\mathrm{TiO}_{2}$, the absorption, scattering and emission of photons by the catalyst restrict the reactive volume such that annular reactors with narrow channels are preferred. Accordingly, increasing aggregate size results in a reduced percentage of the total catalyst audit that is able to reside within this reactive volume at any point in time and hence this inhibits degradation.

Considering the shape as well as size of the formed aggregates completes the picture as the two factors can change independently. This is provided from analysis of aggregate structural properties in the current study through measurement of the particle volumetric fractal dimension (df) by small angle light scattering (SALLS). The fractal dimension provides 
information on the particle shape and openness of structure. An increase in the fractal dimension infers an increase in the aggregates compaction. Hence it is an indication of the total available catalyst surface and the degree by which UV may penetrate into the TiO2 aggregate [41, 42]. It is therefore postulated that an aggregate with a more porous, open structure would enable greater opportunity for UV light to penetrate and photoactivate $\mathrm{TiO}_{2}$, hence increase the reactive volume and improve contaminant removal

In the absence of alkalinity the df was 0.42 which increased to 1.86 and 2.05 for alkalinities of 10 and $20 \mathrm{mg} \mathrm{L}^{-1}$. A further increase in alkalinity resulted in a reduction in df to between 1.52 and 1.58 at all subsequent alkalinity levels tested. The changes in df reported here are consistent with a previous study utilizing SALLS to investigate the reversibility of floc structural properties during aggregation in the presence of $\mathrm{NaCl}$. In the absence of $\mathrm{NaCl}$ the fractal dimension was 0.6 which then increased to 1.7 during growth before further increasing to 2.05 during periods of elevated shear rate [31]. In the current case the results indicate that the aggregate becomes more compact in the presence of low levels of alkalinity and become slightly more open as the alkalinity increases and stabilises above $20 \mathrm{mg} / \mathrm{L}$ as $\mathrm{CaCO}_{3}$. Translation of the findings to overall removal rates shows that aggregates will form that have a similar df for the vast majority of water sources given that the majority of target waters are medium-alkalinity and few exist below $40 \mathrm{mg} \mathrm{L}^{-1}$. Therefore the principal impact of treating source waters with different alkalinities will be from a change in catalyst aggregate size rather than its structure. This is more clearly shown by the rapid change in the DOC and metaldehyde rate constants concurrent with the size change rather than any significant change in df (Figure 7).

Given that most water sources have significant levels of alkalinity present, the inhibitory impact it has on the $\mathrm{UV} / \mathrm{TiO}_{2}$ process for both micropollutant and bulk contaminant removal means that an amelioration approach must be developed. Ultimately, the improved efficacy of the process requires destabilisation of the aggregation process such that smaller $\mathrm{TiO}_{2}$ clusters 
form in order to increase the degradation rate. Whilst chemical approaches are available they are undesirable due to additional costs and potential impacts on downstream water quality. Future focus should therefore be on mechanical breakage of aggregates before photocatalytic reactions take place.

\section{Conclusions}

The presented data demonstrates the efficacy of AOPs in removing micropollutants in real waters providing a viable approach to the management of currently recalcitrant compounds such as metaldehyde. The potential of $\mathrm{UV} / \mathrm{H}_{2} \mathrm{O}_{2}$ is further demonstrated as a robust treatment to offer an alternative approach to recalcitrant organic compound removal commensurate with DBP compliance as long as sufficient UV dose is applied. For UV/TiO 2 efficiency is dependent on alkalinity-derived aggregation rather than carbonate radical scavenging. Hence, the overall suitability will be further enhanced once technology is developed to ameliorate against the alkalinity derived aggregation of the catalyst in the $\mathrm{UV} / \mathrm{TiO}_{2}$ process which will then enable the further development of a chemical free water treatment approach.

\section{Acknowledgments}

The authors would like to express their gratitude for the financial support for this project by Severn Trent Water Ltd.

\section{References}

[1] B. Morasch, F. Bonvin, H. Reiser, D. Grandjean, L. F. De Alencastro, C. Perazzolo, N. Chèvre, T. Kohn, Occurrence and fate of micropollutants in the Vidy Bay of Lake Geneva, Switzerland. Part II: Micropollutant removal between wastewater and raw drinking water, Environ. Toxicol. Chem. 29 (2010) 1658-1668. 
[2] S. D. Richardson and T. A. Ternes, Water Analysis: Emerging Contaminants and Current Issues, Anal. Chem. 86 (2014) 2813-2848.

[3] M. Farré, S. Pérez, L. Kantiani, D. Barceló, Fate and toxicity of emerging pollutants, their metabolites and transformation products in the aquatic environment, TrAC Trends Anal. Chem. 27 (2008) 991-1007.

[4] W. F. Jardim, C. C. Montagner, I. C. Pescara, G. A. Umbuzeiro, A. M. Di Dea Bergamasco, M. L. Eldridge, F. F. Sodré, An integrated approach to evaluate emerging contaminants in drinking water, Sep. Purif. Technol. 84 (2012) 3-8.

[5] Stuart, M., Lapworth, D., Crane, E. Hart, A., 2012. Review of risk from potential emerging contaminants in UK groundwater, Sci. Tot. Environ. 416, 1-21.

[6] CE 98/83/EC, Council Directive 98/83/EC of 3 November 1998 on the quality of water intended for human consumption.

[7] D.J. Lapworth, N. Baran, M.E. Stuart, R.S. Ward, Emerging organic contaminants in groundwater: A review of sources, fate and occurrence, Environ. Pollut. 163 (2012) 287-303.

[8] Drinking water inspectorate (DWI), 2014. Regional reports on the testing and results of water quality tests, events and technical audit activity (http://dwi.defra.gov.uk/about/annual-report/2014/index.html).

[9] G. Gfrerer, T. Wenzl, X. Quan, B. Platzer, E. Lankmayr, Occurrence of triazines in surface and drinking water of Liaoning Province in Eastern China, J. Biochem. Bioph. Methods 53 (2001) 217-22.

[10] M. Köck-Schulmeyer, A. Ginebreda, S. González, J. L. Cortina, M. López de Alda, D. Barceló, Analysis of the occurrence and risk assessment of polar pesticides in the Llobregat River Basin (NE Spain), Chemosphere 86 (2012) 8-16. 
[11] N. E. Glozier, J. Struger, A. J. Cessna, M. Gledhill, M. Rondeau, W. R. Ernst, M. A. Sekela, S. J. Cagampan, E. Sverko, C. Murphy, J. L. Murray, D. B. Donald, Occurrence of glyphosate and acidic herbicides in select urban rivers and streams in Canada, Environ. Sci. Pollut. Res. 19 (2007) 821-834.

[12] D. Munari, A.J.C. Semiao, B. Antizar-Ladislao, Retention of pesticide Endosulfan by nanofiltration: Influence of organic matter-pesticide complexation and solute-membrane interactions, Water Res. 47 (2013) 3484-3496.

[13] V. Camel, A. Bermond, The use of ozone and associated oxidation processes in drinking water treatment, Water Res. 32 (1998) 3208-3222.

[14] B.A. Wols, C. H. M. Hofman-Caris, Review of photochemical reaction constants of organic micropollutants required for UV advanced oxidation processes in water, Water Res. 46 (2012) 2815-2827.

[15] M. Pera-Titus, V. García-Molina, M. A. Baños, J. Giménez, S. Esplugas, Degradation of chlorophenols by means of advanced oxidation processes: a general review, App. Catal. B, 47 (2004) 219-256.

[16] O. Autin, J. Hart, P. Jarvis, J. MacAdam, S.A. Parsons, B. Jefferson, The impact of background organic matter and alkalinity on the degradation of the pesticide metaldehyde by two advanced oxidation processes: $U V / \mathrm{H}_{2} \mathrm{O}_{2}$ and $\mathrm{UV} / \mathrm{TiO}_{2}$, Water Res. 47 (2013) 2041-2049. [17] I. Carra, J. A. Sánchez Pérez, S. Malato, O. Autin, B. Jefferson, P. Jarvis, Performance of different Advanced Oxidation Processes for tertiary wastewater treatment to remove the pesticide acetamiprid, J. Chem. Technol. Biotechnol., In Press. DOI: 10.1002/jctb.4577 [18] P. LeClech, E-K. Lee, V. Chen, Hybrid photocatalysis/membrane treatment for surface waters containing low concentrations of natural organic matters, Water Res. 40 (2006) 323330. 
[19] S. Liu, R. Fabris, C. Chow, M. Drikas, R. Amal, Comparison of photocatalytic degradation of natural organic matter in two Australian surface waters using multiple analytical techniques, Geochem. 41 (2010) 124-129.

[20] M. Silampa, A. Matilainen, Natural Organic Matter in Water: Characterization and Treatment Methods, Butterworth-Heinemann. Chapter 6, 2014.

[21] DWI (2000). The Water Supply (Water Quality) Regulations 2000. Statutory Instruments. No. 3184. Water, England and Wales. Drinking Water Inspectorate [22] WHO (2006). Guidelines for Drinking-water Quality. Third Edition Incorporating the first addenda. Volume 1. Recommendations. World Health Organization. [23] Toor, R., Mohseni, M., 2007. UV-H2O2 based AOP and its integration with biological activated carbon treatment for DBP reduction in drinking water. Chemosphere 66, 20872095.

[24] S. Sarathy, M. Mohseni, Effects of UV/H2O2 advanced oxidation on chemical characteristics and chlorine reactivity of surface water natural organic matter, Water Res. 44 (2010) 4087-4096.

[25] D. Gerrity, B. Mayer, H. Ryu, J. Crittended, M. Abbaszadegan, A comparison of pilot scale photocatalysis and enhanced coagulation for disinfectant by-product mitigation, Water Res. 43 (2009) 1597-1610.

[26] C. von Sonntag, and H.P. Schuchmann, UV disinfection of drinking water and byproduct formation - some basic considerations, J. Water Supply: Res. Technol., 42 (1992) 67-74.

[27] J.P. Croué, G.V. Korshin, and M.M. Benjamin, Characterization of natural organic matter in drinking water, American Water Works Association Research Foundation, report 90780, 2000, Denver, CO, USA. 
[28] T. Bond, E. H. Goslan, S. A. Parsons, B. Jefferson, A critical review of trihalomethane and haloacetic acid formation from natural organic matter surrogates, Environ. Technol. Rev. 1 (2012) 93-113.

[29] O. Autin, J. Hart, P. Jarvis, J. MacAdam, S.A. Parsons, B. Jefferson, Comparison of $\mathrm{UV} / \mathrm{H}_{2} \mathrm{O}_{2}$ and $\mathrm{UV} / \mathrm{TiO}_{2}$ for the degradation of metaldehyde: Kinetics and the impact of background organics, Water Res. 46 (2012) 5655-5662.

[30] APHA Standard Methods, 1992. American Public Health Association, Washington DC, USA, $18^{\text {th }}$ ed.

[31] P. Jarvis, B. Jefferson, and S.A. Parsons, Breakage, Regrowth and Fractal Nature of Natural Organic Matter Flocs, Environ. Sci. Technol. 39 (2005) 2307-2314.

[32] I.K. Konstantinou, T.A. Albanis, TiO2-assisted photocatalytic degradation of azo dyes in aqueous solution: Kinetic and mechanistic investigations, App. Catal. B, 49 (2004) 1-14. [33] S. Malato, P. Fernandez-lbanez, M.I. Maldonado, J. Blanco, W. Gernjak, Decontamination and disinfection of water by solar photocatalysis: Recent overview and trends, Catal. Today 147 (2009) 1-59.

[34] J. Virkutyte, R. J. Varma, V. Jegatheesan, Treatment of micropollutants in water and wastewater, 2010. IWA Publishing ISBN 10:1843393166.

[35] K.K. Philippe, C. Hans, J. MacAdam, B. Jefferson, Hart, J., Parsons, S.A. Photocatalytic oxidation of natural organic matter surrogates and the impact on trihalomethane formation potential, Chemosphere, 81 (2010) 1509-1516. [36] J. Fu, M. Ji, Y. Zhao, and L. Wang, Kinetics of aqueous photocatalytic oxidation of fulvic acids in a photocatalysis-ultrafiltration reactor, Sep. Purif. Technol. 50 (2006) 107-113. [37] P.H. Hutton, and F.I. Chung, Correlating Trihalomethane Data. J. Environ. Eng. ASCE, 120 (1994) 219-241. 
[38] D. Avisar, I. Horovitz, L. Lozzi, F. Ruggieri, M. Baker, M.L. Abel, and H. Mamane, Impact of water quality on removal of carbamazepine in natural waters by $\mathrm{N}$-doped $\mathrm{TiO}_{2}$ photocatalytic thin film surfaces, J. Hazard. Mat. 244-245 (2013) 463-471.

[39] Yang, T., Doudrick, K. and Westerhoff, P., 2013. Photocatalytic reduction of nitrate using titanium dioxide for regeneration of ion exchange brine. Water Res. 47, 1299-1307. [40] G. LiPuma, B. Toepfer, and A. Gora, Photocatalytic oxidation of multicomponent systems of herbicides: Scale-up of laboratory kinetics rate data to plant scale, Catal. Today 124 (2007)124-132.

[41] L. Piscitelle, R. Segars, Effect of particle size distribution in determining a powder's fractal dimension by single gas BET: A mathematical model, J. Colloid Interface Sci. 149 (1992) 226-232.

[42] S. Arasan, S. Akbulut, A. S. Hasiloglu, The relationship between the fractal dimension and shape properties of particles, KSCE J. Civ. Eng. 15 (2011) 1219-1225. 


\section{FIGURE CAPTIONS}

Figure 1. Influence of UV dose on the (a) $\mathrm{UV} / \mathrm{TiO} \mathrm{O}_{2}$ process and (b) $\mathrm{UV} / \mathrm{H}_{2} \mathrm{O}_{2}$ process in relation to the removal of bulk organic matter $\left(3 \mathrm{mg} \mathrm{L}^{-1}\right.$ of leucine, $4.6 \mathrm{mg} \mathrm{L}^{-1}$ of serine and $2.4 \mathrm{mg} \mathrm{L}^{-}$ ${ }^{1}$ of resorcinol), DOC (5 mg L-1) and the micropollutant metaldehyde $\left(10 \mu \mathrm{g} \mathrm{L}^{-1}\right)$.

Figure 2. Influence of UV dose on DOC and micropollutant metaldehyde removal in natural water with $\mathrm{UV} / \mathrm{TiO}_{2}$ and $\mathrm{UV} / \mathrm{H}_{2} \mathrm{O}_{2}$.

Figure 3. THMFP under UVC doses up to $40000 \mathrm{~mJ} \mathrm{~cm}^{-2}$ in synthetic and real water with $\mathrm{UV} / \mathrm{TiO}_{2}$ and $\mathrm{UV} / \mathrm{H}_{2} \mathrm{O}_{2}$.

Figure 4. Influence of alkalinity on the DOC and metaldehyde pseudo-first order kinetic constants with $\mathrm{UV} / \mathrm{TiO}_{2}$ degradation. Alkalinity expressed as $\mathrm{mg} / \mathrm{L}$ as $\mathrm{CaCO}_{3}$.

Figure 5. THMFP under different UVC doses and alkalinity $\left(0,5,10,20,40,60 \mathrm{mg} \mathrm{L}^{-1}\right.$ as $\mathrm{CaCO}_{3}$ ) with UV/TiO

Figure 6. Impact of alkalinity on the photocatalyst aggregate size distribution (alkalinity as mg $\left.\mathrm{L}^{-1} \mathrm{CaCO}_{3}\right)$ 
Figure 7. The link between median aggregate size and fractal dimension on the DOC and metaldehyde apparent first order rate constant. 


\section{Graphical Abstract}

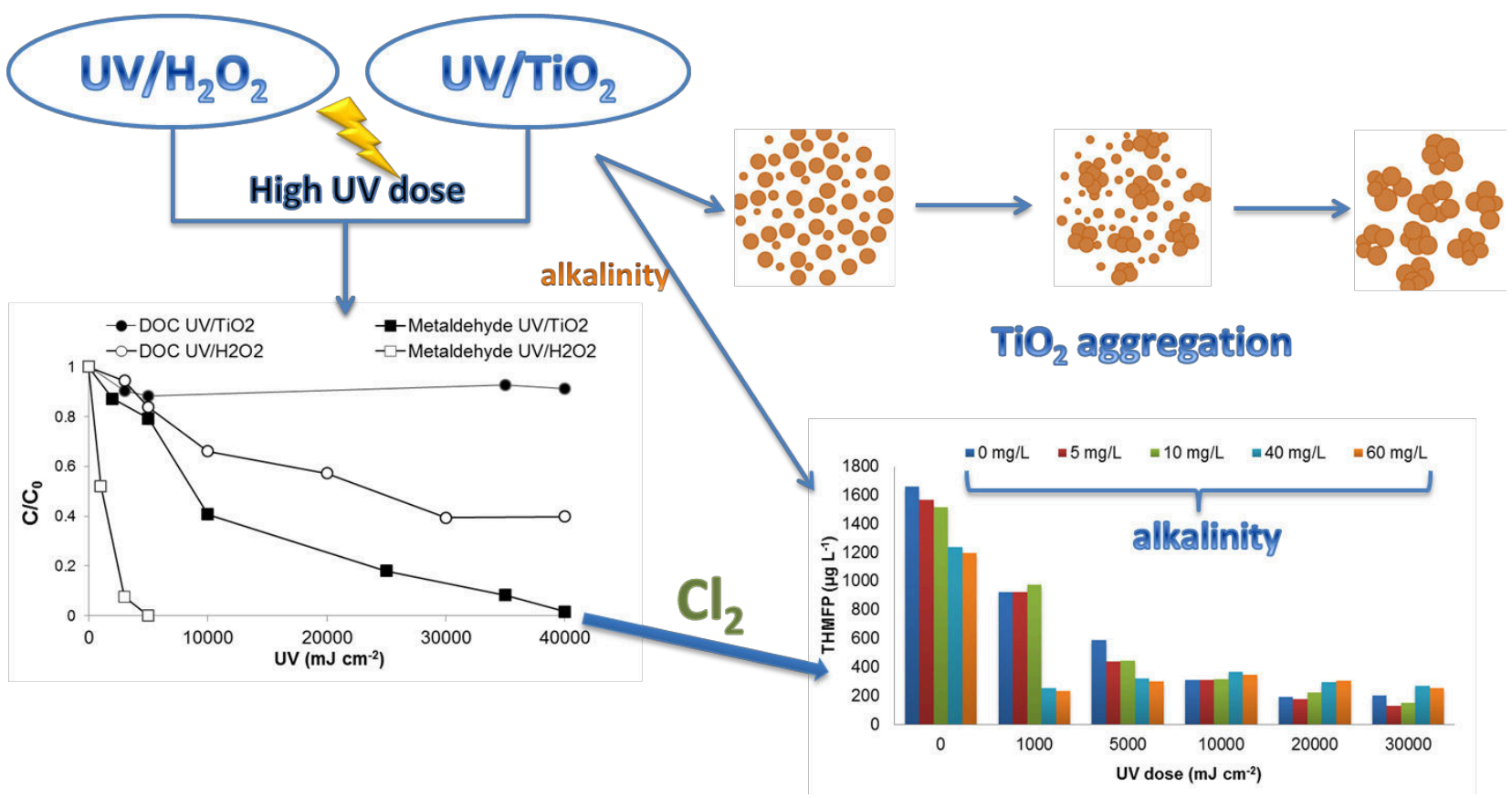


Table 1.Metaldehyde, serine, leucine and resorcinol properties.

\begin{tabular}{|c|c|c|c|c|c|c|}
\hline $\begin{array}{l}\text { Organic } \\
\text { compound }\end{array}$ & Structure & $\begin{array}{l}\mathrm{k}_{\mathrm{HO}} \cdot \\
\left(\mathrm{M}^{-1} \mathrm{~s}^{-1}\right)\end{array}$ & $\begin{array}{l}\xi_{254^{b}} \\
\left(M^{-1} \mathrm{~cm}^{-1}\right)\end{array}$ & $\log K_{o w}{ }^{b}$ & $\begin{array}{c}\text { MW } \\
\left(\mathrm{g} \mathrm{mol}^{-1}\right)\end{array}$ & Classification $^{b}$ \\
\hline Metaldehyde & & $1.3 \times 10^{9} \mathrm{a}$ & 19.0 & 0.12 & 176 & Hydrophobic \\
\hline Serine & & $3.2 \times 10^{8} \mathrm{~b}$ & 0.3 & -3.07 & 105 & Hydrophilic \\
\hline Leucine & & $1.7 \times 10^{9 b}$ & 0.5 & -1.52 & 131 & Transphilic \\
\hline Resorcinol & & $1.2 \times 10^{10 c}$ & 559.8 & 0.80 & 110 & Hydrophobic \\
\hline
\end{tabular}

a: value from Autin et al., 2012; b: values from Xu and Chance, 2005; c: value from Minakata et al., 2009; d: values from Chemspider chemical data base search. Available at: http://www.chemspider.com [accessed 2015]. 
Table 2. Metaldehyde and DOC kinetic degradation constants with $\mathrm{UV} / \mathrm{H}_{2} \mathrm{O}_{2}$ and $\mathrm{UV} / \mathrm{TiO} \mathrm{O}_{2}$.

\begin{tabular}{cccccccccc}
\hline \multirow{2}{*}{ Water } & \multicolumn{4}{c}{$\mathrm{UV} / \mathrm{H}_{2} \mathrm{O}_{2}$} & \multicolumn{4}{c}{$\mathrm{UV} / \mathrm{TiO}_{2}$} \\
\cline { 2 - 10 } Matrix & \multicolumn{2}{c}{ Metaldehyde } & \multicolumn{2}{c}{$\mathrm{DOC}$} & \multicolumn{2}{c}{ Metaldehyde } & \multicolumn{2}{c}{$\mathrm{DOC}$} \\
& $\mathrm{k}^{\prime}$ & $\mathrm{r} 2$ & $\mathrm{k}^{\prime}$ & $\mathrm{r} 2$ & $\mathrm{k}^{\prime}$ & $\mathrm{r} 2$ & $\mathrm{k}^{\prime}$ & $\mathrm{r} 2$ \\
\hline Synthetic & 8.69 & 0.994 & 0.88 & 0.986 & 2.28 & 0.999 & 0.49 & 0.994 \\
Natural & 7.06 & 0.989 & 0.26 & 0.973 & 0.58 & 0.989 & - & - \\
\hline
\end{tabular}


Figure 1
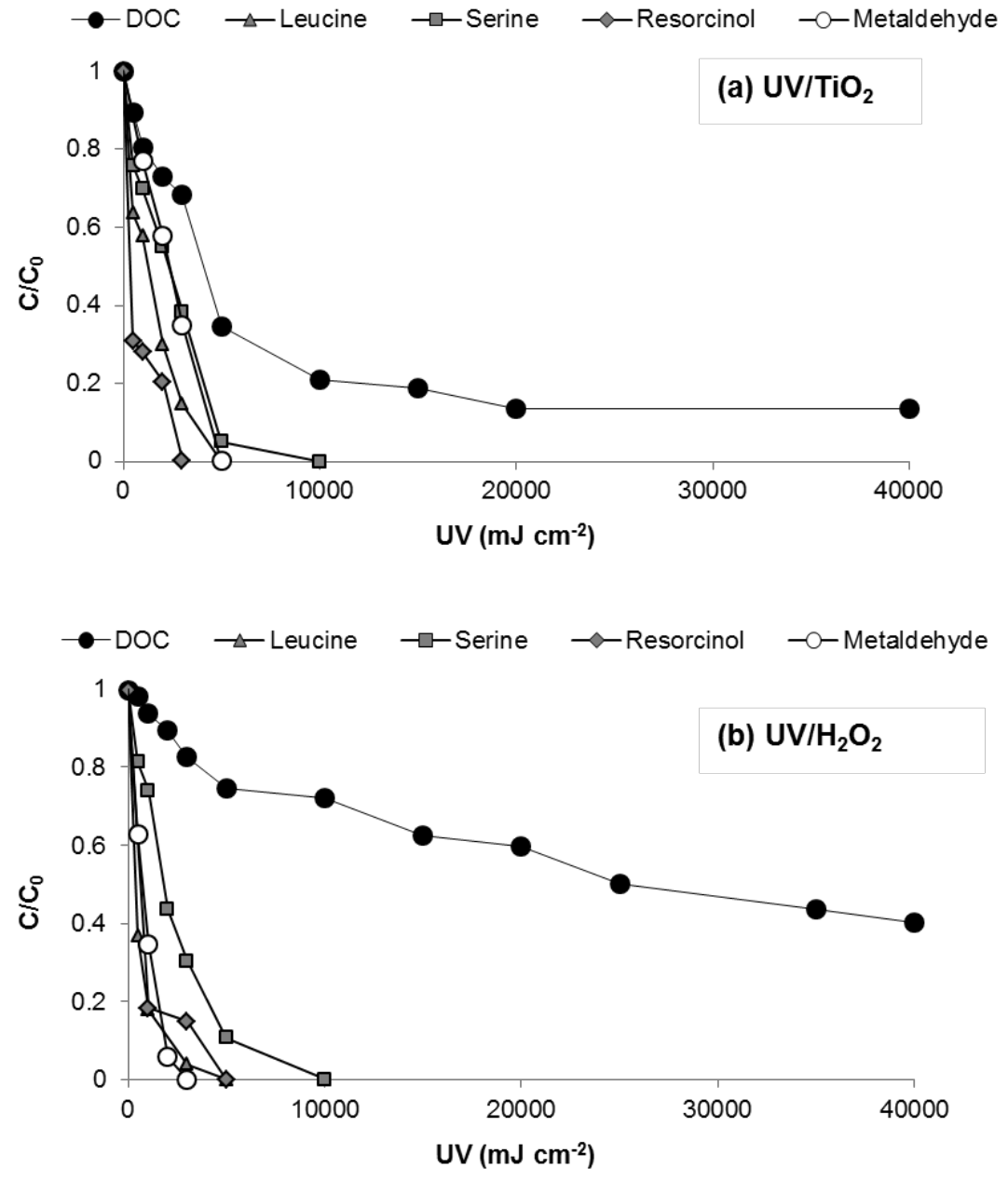
Figure 2

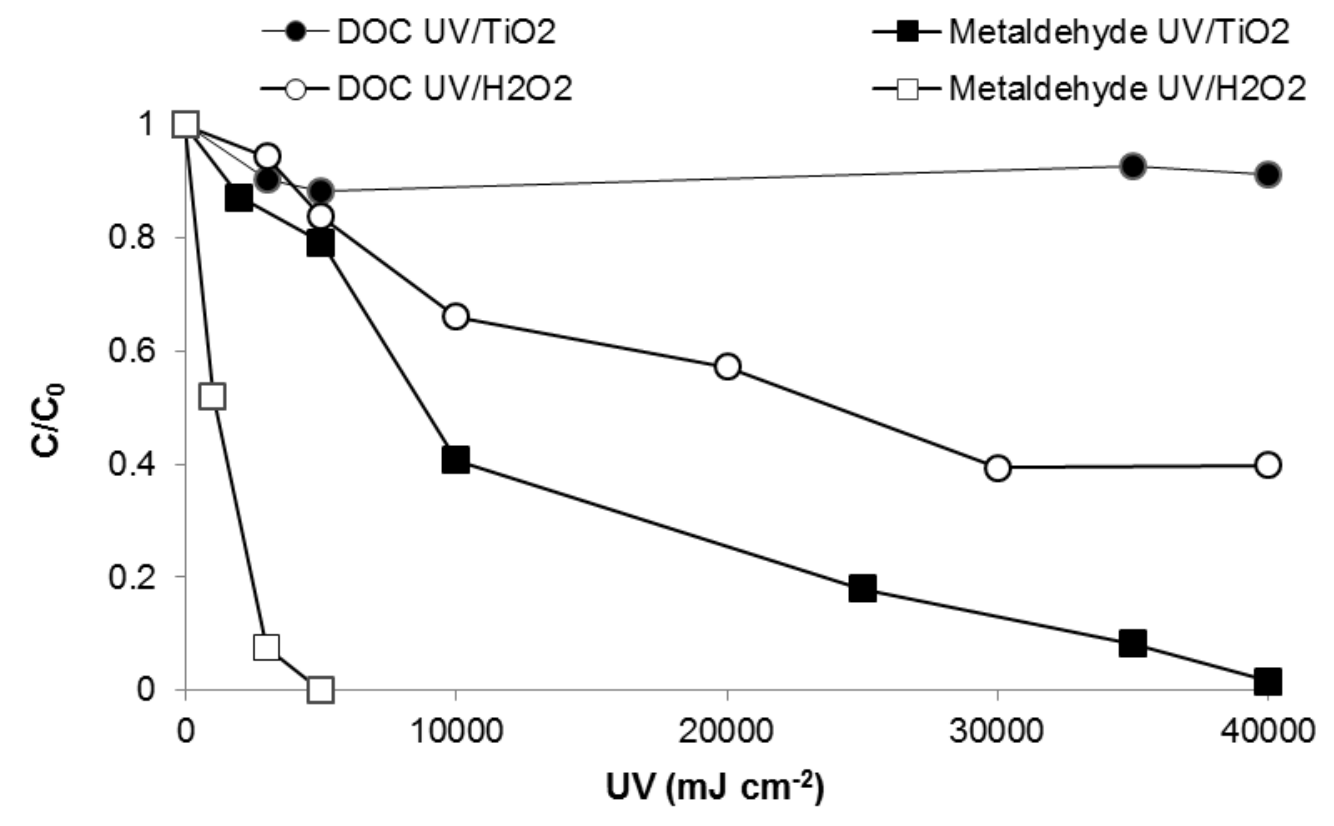


Figure 3

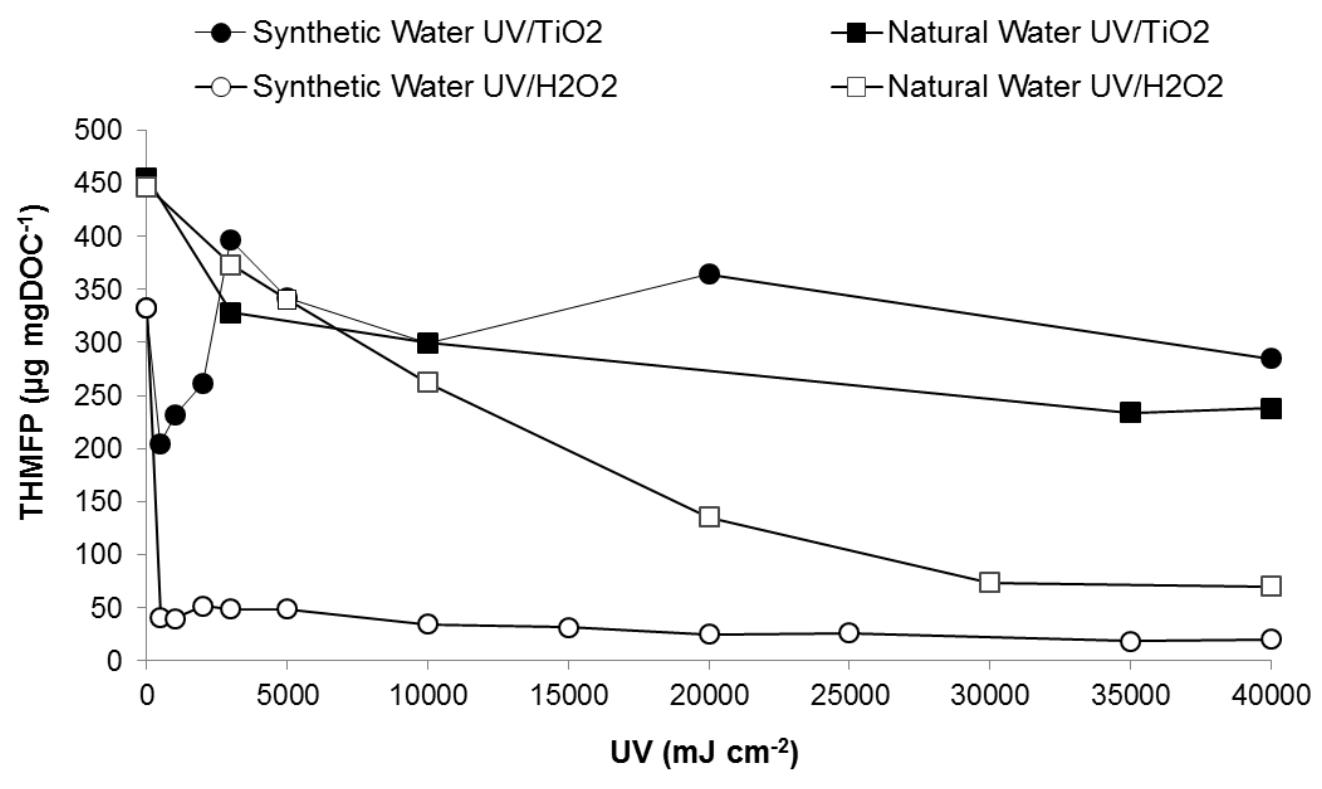


Figure 4

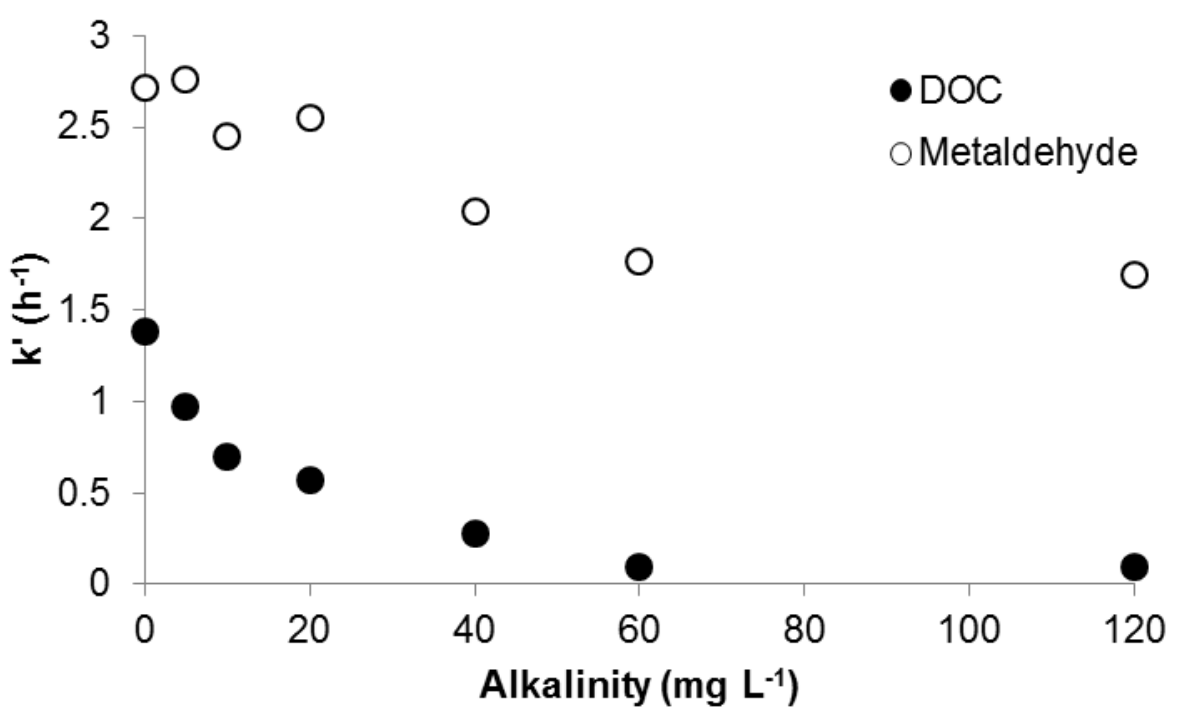


Figure 5

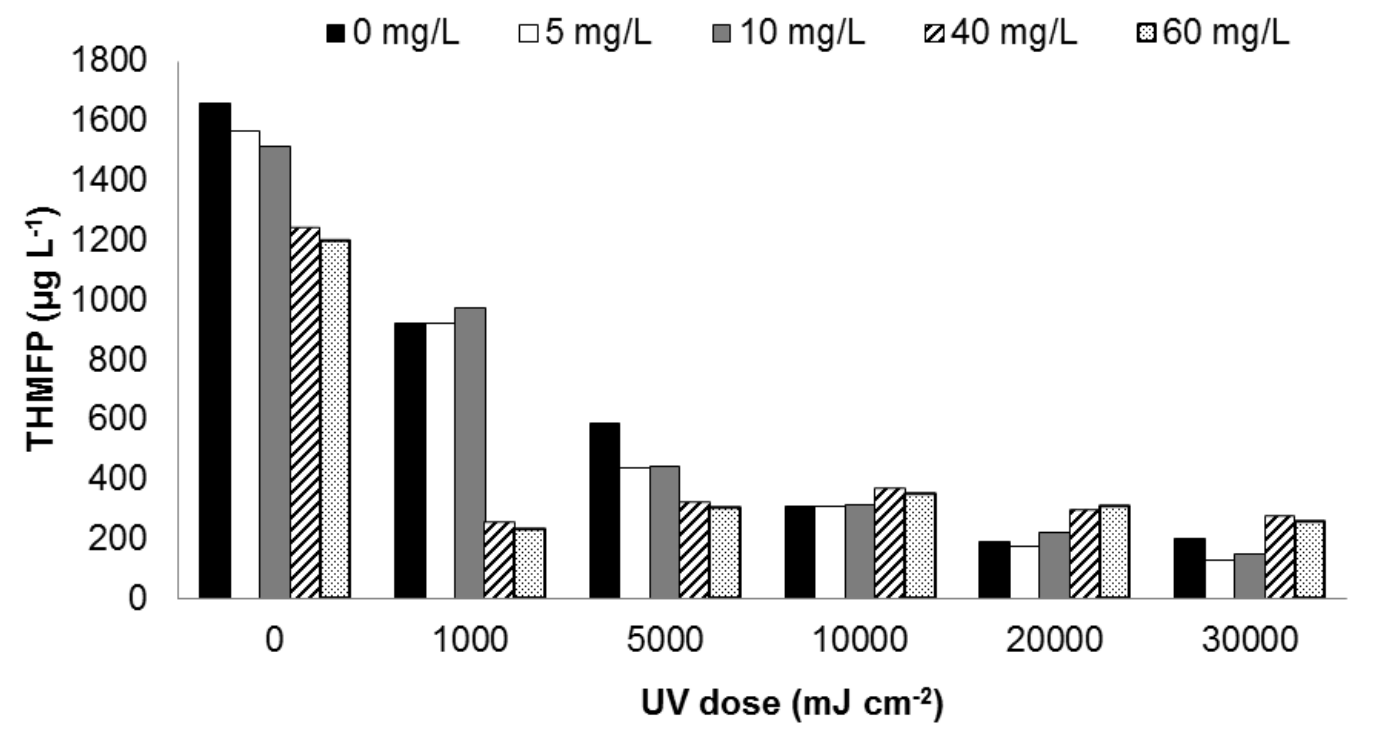


Figure 6

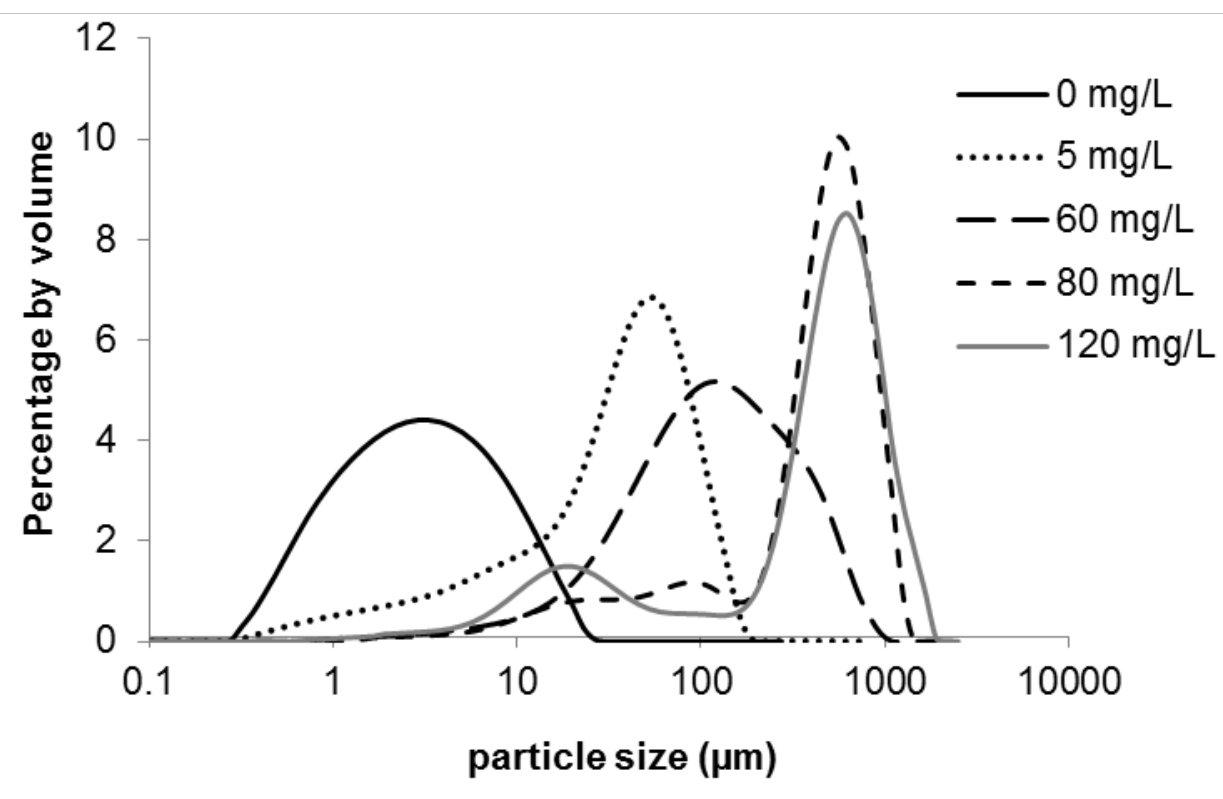


Figure 7

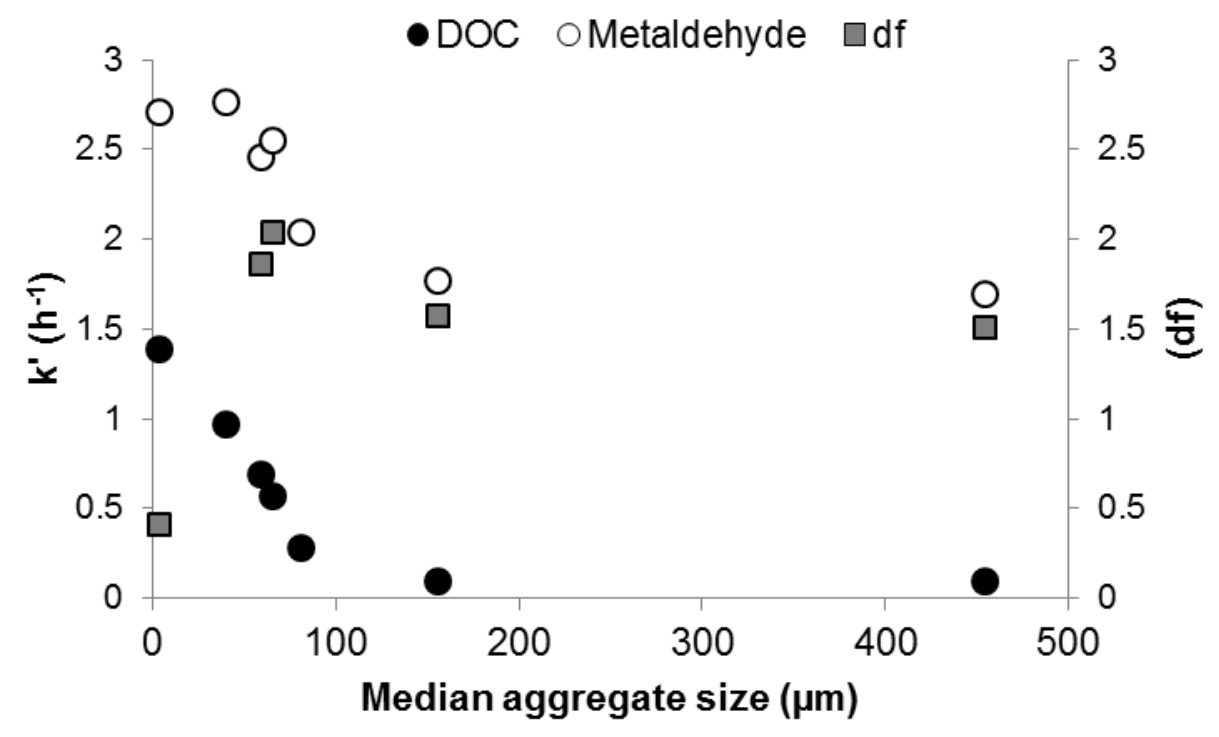

